\title{
Discusión del artículo "Complicaciones de los tornillos de bloqueo intermaxilar en el tratamiento de las fracturas mandibulares"
}

\author{
Discussion of the article "Complications of self-tapping bone screws for maxillomandibular fixation in the treatment \\ of jaw fracture"
}

Los tornillos de fijación intermaxilar (FIM) son uno de esos descubrimientos empíricos que a veces ocurren en cirugía y que hasta que no pasan los años no se es consciente de la transcendencia que tienen para nuestra práctica diaria. Algo aparentemente tan simple no fue descrito en la literatura científica hasta el año 1989.' Desde entonces su uso se comenzó a generalizar y, cómo no, la industria médica empezó a realizar diseños más específicos de estos tornillos. Hay que recordar que entonces al no haber tornillos especiales para la FIM utilizábamos los tornillos estándares de titanio de las miniplacas de 1,5 o de $2 \mathrm{~mm}$ de diámetro (Fig. 1); por supuesto estos tornillos requerían un fresado previo del lecho, incluso antes de colocarlos se abría la mucosa oral ya que ponerlos transmucosos parecía una "herejía". Más tarde, comenzaron a aparecer tornillos de FIM con un diseño más evolucionado: una cabeza más ancha y redondeada que un tornillo normal para evitar las úlceras de decúbito y que la mucosa oral los tapara, un pequeño agujero en la cabeza para poder enhebrar un alambre en caso de una FIM rígida, un pequeño canal entre la cabeza y la

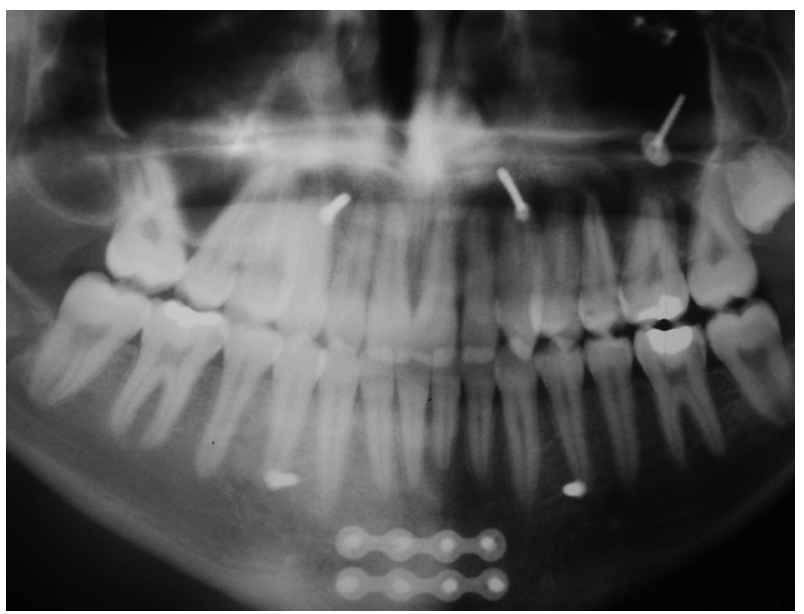

Figura 1. Ortopantomografía mostrando el empleo de tornillos estándares de miniplacas de $1.5 \mathrm{~mm}$ de diámetro para realizar una FIM en una fractura mandibular.

Figure 1. Orthopantomography showing the use of standard 1.5 $\mathrm{mm}$ diameter miniplate screws to perform MMF in a mandibular fracture.

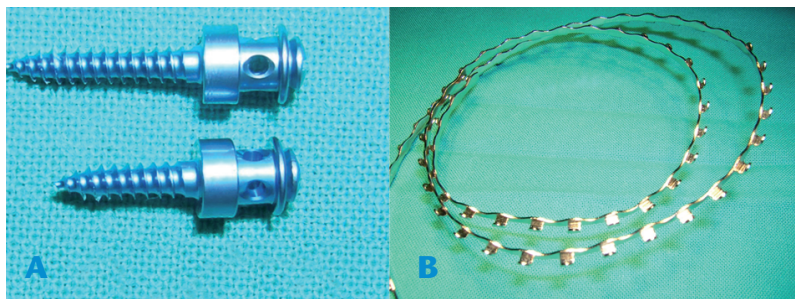

Figura 2. A. Tornillos de FIM de acero. B. Férula de Ehrlich. Figure 2. A. Steel MMF screws. B. Ehrlich splint.
Maxillomandibular fixation (MMF) screws are one of those empirical discoveries that are made in surgery sometimes, whose importance in daily practice is only recognized years later. Something apparently as simple as screws was not described in the scientific literature until 1989. ${ }^{1}$ Since then, the use of MMF became generalized and, naturally, the medical industry began to come up with more specific screw designs. It should be remembered that there were no special screws for MMF then and we used the standard 1.5$\mathrm{mm}$ or 2-mm diameter titanium miniplate screws (Fig. 1). Of course, these screws required first drilling in the bed and the oral mucosa was opened before they were placed. Inserting the screws through the mucosa seemed "heretical." Later, MMF screws of more advanced design began to appear: they had a wider and rounder head than a normal screw to prevent gomas en caso de FIM elástica, así como unas pestañas en cruz para su fácil colocación y retirada sin necesitar destornilladores especiales (Fig. 2A). También la industria trató de reducir costes fabricando estos tornillos en acero en lugar de en titanio, ya que al fin y al cabo era un material que debía de retirarse, aunque al principio su menor resistencia hacía que se partieran con cierta frecuencia en la zona de la unión entre la cabeza y la rosca. ${ }^{2}$ Pero el gran avance en el diseño de los mismos fue la incorporación de una punta muy afilada que facilitaba su colocación transmucosa y de un sistema autoroscante que hacía innecesario el uso de brocas previamente a su inserción, incluso en huesos muy pressure sores and the encroachment of the oral mucosa, a small hole in the head to allow a wire to be threaded in the case of rigid MMF, a small canal between the head and shaft to comfortably lodge elastic bands in the case of elastic MMF, as well as a cross-marked tab to easily position and remove the screw without having to use special screwdrivers (Fig. 2A). The industry also tried to reduce costs by manufacturing the screws in steel instead of titanium since, after all, the material was going to be removed later. However, the lower resistance of the steel screws at first led to frac- 
corticales y duros como en la mandíbula. Además, esta innovación protege las raíces de los dientes de ser dañadas durante la inserción, ya que al notar un aumento en la resistencia, el tornillo se desvía y rodea la raíz dental. Una evolución de estos tornillos la tenemos tremendamente de moda hoy en día: los microtornillos o microimplantes para la tracción ortodóncica, técnica perfectamente asumida en la actualidad y que ofrece unos excelentes resultados. ${ }^{3}$

Los autores del presente artículo hacen una revisión meticulosa de su experiencia en el empleo de estos tornillos para el tratamiento de las fracturas mandibulares. Aunque ésta es la principal indicación, no es la única ya que habitualmente los empleamos también en cirugía ortognática ${ }^{4}$ en cirugía oncológica para mantener la oclusión dental antes de colocar un injerto óseo, así como en otros tipos de fracturas como las maxilares o las dentoalveolares. De hecho, tan solo se han publicado 2 artículos específicos sobre complicaciones de estos tornillos, aunque otras revisiones clínicas describen la incidencia de complicaciones con esta técnica.

Las ventajas de estos tornillos son perfectamente explicadas por los autores, la fundamental es el ahorro de tiempo quirúrgico, también el poder colocarlos mediante anestesia local en fracturas simples y, cómo no, evitar el riesgo de pinchazos accidentales que había cuando la FIM se realizaba con las tediosas férulas de Ehrlich y alambres (Fig. 2B); hay que recordar que uno de los primeros usos de estos tornillos era para el tratamiento de fracturas en enfermos con infección por el VIH o por el VHB. Por el contrario, uno de sus principales problemas lo encontramos, tal y como señalan en el presente artículo, en la reducción de fracturas muy conminutas o en pacientes edéntulos. Además, es una técnica que, aunque sencilla para un cirujano oral y maxilofacial, no deja de ser una técnica "ciega" que, en manos inexpertas, puede aumentar tremendamente el índice de complicaciones. ${ }^{5}$ Recuerdo ahora el caso que ocurrió en un hospital comarcal en el que las fracturas faciales eran operadas por el traumatólogo, el cual estaba muy contento porque "había encontrado un agujerito muy adecuado para introducir la aguja de Kirschner a lo largo del interior del cuerpo mandibular en el tratamiento de las fracturas mandibulares" (sic). Evidentemente, éste era el agujero mentoniano por donde salía el nervio dentario inferior. Supongo que éste fuera un hecho aislado y hoy en día con la excelente formación de nuestros especialistas y la implantación de nues- tures at the junction between the head and the shaft with some frequency. ${ }^{2}$ A major advance in the design of these screws was the addition of a very sharp tip to facilitate transmucosal placement and of a self-tapping system that made it unnecessary to drill before insertion, even in hard bones like the jaw and bone with a thick cortical. This innovation also protects dental roots from damage during screw insertion because when the screw encounters increased resistance, it turns aside and around the dental root. An advance in these screws is now extremely popular: microscrews or microimplants for orthodontic traction. This technique now is perfectly integrated into practice and produces excellent results.

The authors of the present article meticulously review their experience with the use of these screws for the treatment of mandibular fractures. Although this is the main indication of these screws, it is not the only indication. They are routinely used in orthognathic surgery, ${ }^{4}$ in oncologic surgery to maintain dental occlusion before implanting a bone graft, and in other types of fracture, such as maxillary or tooth socket fractures. In fact, only two specific articles have been published on the complications of these screws, although other clinical reviews describe the incidence of complications with this technique.

The advantages of these screws are explained perfectly by the authors. The fundamental advantage is that they save surgical time and can be inserted under local anesthesia in simple fractures. Of course, they also prevent the risk of accidental pricks that existed when MMF was done with the tedious Ehrlich splints and wires (Fig. 2B). It should be remembered that one of the first uses of these screws was for to manage fractures in patients with HIV or HBV infection. In contrast, one of their main problems, as indicated in the present article, is in the reduction of highly comminuted fractures or in toothless patients. In addition, it is a technique that, while simple for an oral and maxillofacial surgeon, is still a "blind" technique. In inexperienced hands, they can tremendously increase the rate of complications. ${ }^{5}$ 
tra especialidad en los diversos hospitales, tan solo quede en una anécdota. Respecto al índice de complicaciones que indican los autores coinciden con otras revisiones publicadas en estar en torno a un $4 \% .6,7$ Una revisión más reciente (2007) de Coletti y cols. habla de un $39 \%$ y de un $8 \%$ de pacientes que acumulan más de una complicación; ${ }^{8}$ el índice de daño a las raíces fue del $4 \%$, siendo en el presente artículo del 4,4\%. ${ }^{9}$ Algunos autores han sugerido una asociación entre el índice de complicaciones con los tornillos y la experiencia del cirujano, dado que en muchas ocasiones estos tornillos de bloqueo son colocados por los residentes o ayudantes del cirujano principal. 5,9

Tan solo quiero hacer unas sencillas consideraciones al estupendo artículo que nos ocupa. Nosotros últimamente y en algunos casos colocamos tres tornillos en cada arcada, uno de ellos en la línea media, ya que ésto permite tener un mejor control del vector de aplicación de las fuerzas sobre los tornillos (Fig. 3); además, hay que pensar que las gomas que habitualmente usamos son las de ortodoncia y, a veces, son demasiado cortas para unir tornillos muy alejados. También, elegimos habitualmente los tornillos más cortos (normalmente de 8 u $11 \mathrm{~mm}$ de longitud), ya que así evitamos algunas complicaciones perforando las dos corticales, sobre todo en la mandíbula. Por otro lado, tal y como sugieren los autores, solemos insertar los tornillos en la unión entre la encía insertada y la libre, para evitar úlceras de decúbito (Fig. 4). En caso de emplear esta FIM en cirugía ortognática (en osteotomías mandibulares subcondíleas) o en fracturas panfaciales en algunas ocasiones ponemos 4 tornillos o más en cada arcada (Fig. 5), dos de ellos en la zona molar, aplicando la fuerza sobre el hueso y no mediante el habitual bloqueo elástico sobre las perchas de la ortodoncia que pueden provocar movimientos dentales no deseados (Fig. 6). ${ }^{10}$

\section{Bibliografía}

1. Arthur G, Berardo N. A simplified technique of maxillomandibular fixation. J Oral Maxillofac Surg 1989;47:1234.

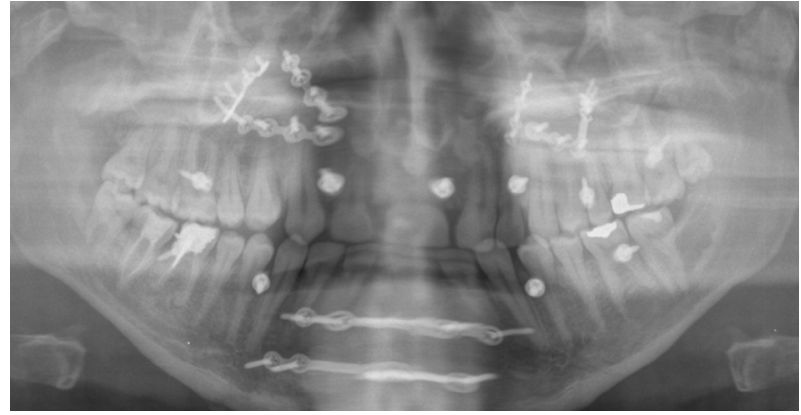

Figura 5. Múltiples tornillos de FIM para fijar una fractura panfacial.

Figure 5. Multiple MMF screws to immobilize a panfacial fracture.
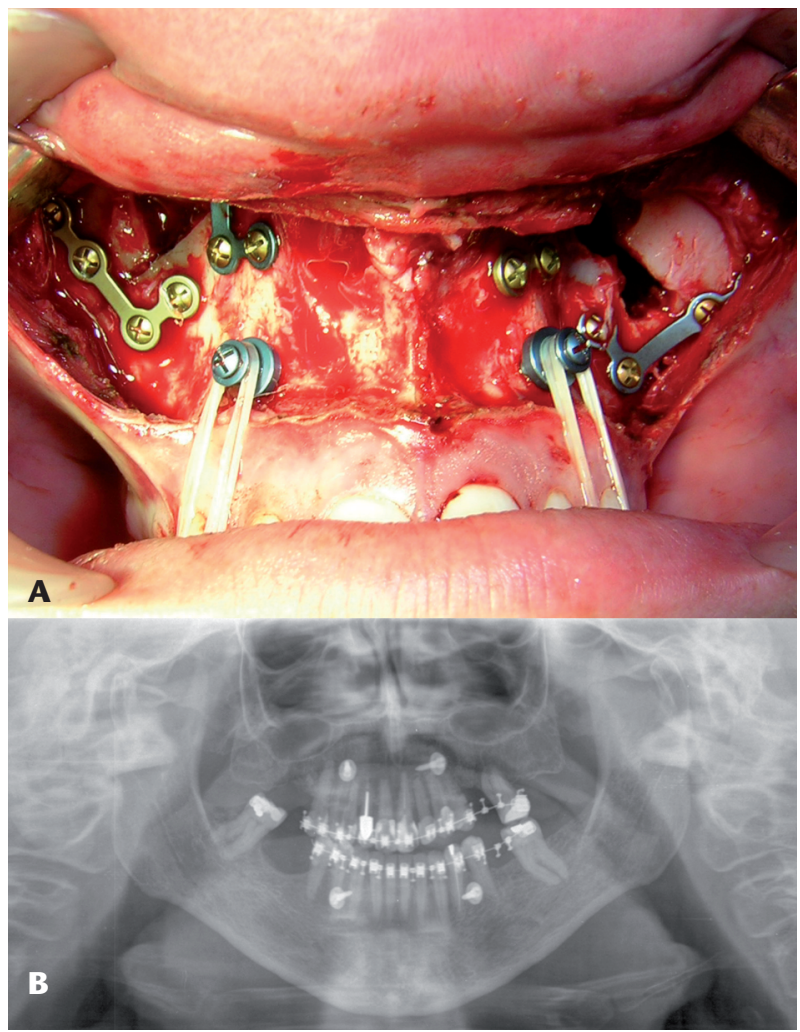

Figura 6. A. Imagen quirúrgica de un caso de cirugía ortognática con un bloqueo elástico aplicado sobre el hueso y no sobre los dientes. B. Ortopantomografía de un caso de cirugía ortognática monomaxilar con osteotomía subcondílea bilateral y setback mandibular, donde se aprecia la FIM realizada sobre tornillos para preservar los dientes que aparecen con poco soporte óseo.

Figure 6. A. Surgical image of a case of orthognathic surgery with elastic bands applied to the bone and not to the teeth. B. Orthopantomography of a case of single maxillary orthognathic surgery with bilateral subcondylar osteotomy and mandibular setback, where MMF on screws to preserve teeth with little bone support is appreciated.
I recall a case that occurred in a regional hospital in which facial fractures were operated on by a traumatologist, who was very satisfied because he or she "had found a very useful hole for introducing a Kirschner needle into the mandibular body for the treatment of mandibular fractures" (sic). Evidently, this is the mental foramen, out of which the inferior dental nerve emerges. I trust that this is an isolated occurrence and that nowadays, with the excellent training of our specialists and the implantation of our specialty in hospitals, it is merely anecdotal. The complication rate that the authors cite coincides with other reviews, about $4 \% .6,7 \mathrm{~A}$ more recent review (2007) by Coletti et al. mentions $39 \%$, with $8 \%$ of patients who accumulate more than one complication; 8 the rate of root damage was $4 \%$, whereas in the present article it is 4.4\%. ${ }^{9}$ Some authors have suggested an association between the complication rate with these screws and the surgeon's experience, because these self-tapping bone screws on many occasions are placed by medical residents or surgical assistants. 5,9

I would only like to make a few simple observations on the splendid article discussed here. Recently, in some cases, we have placed three screws in each dental arcade, one midline, because this gives us better control over the vector of forces applied to the screws (Fig. 3). In addition, the elastic bands usually used are for orthodontics and they are sometimes too short to join screws that are very separated. Also, we usually choose the shortest screws (normally 8 or $11 \mathrm{~mm}$ long), because this allows us to avoid some complications of perforating two cortical layers, particularly in 
2. Gibbons AJ, Evans MJ, Abdullakutty A, Grew NR. Interesting case: Arch bar support using self-drilling intermaxillary fixation screws. Br J Oral Maxillofac Surg 2005;43:364.

3. Polat-Ozsoy O, Kircelli BH, Arman-Ozçirpici A, Pektafl ZO, Uçkan S. Pendulum appliances with 2 anchorage designs: conventional anchorage vs bone anchorage. Am J Orthod Dentofacial Orthop 2008;133:339.

4. Choi BH, Zhu SJ, Han SG, Huh JY, Kim BY, Jung JH. The need for intermaxillary fixation in sagittal split osteotomy setbacks with bicortical screw fixation. Oral Surg Oral Med Oral Pathol Oral Radiol Endod 2005;100:292.

5. Holmes $\mathrm{S}$, Hutchison I. Caution in use of bicortical intermaxillary fixation screws. Br J Oral Maxillofac Surg 2000;38:574.

6. Coburn DG, Kennedy DW, Hodder SC. Complications with intermaxillary fixation screws in the management of fractured mandibles. Br J Oral Maxillofac Surg 2002;40:241.

7. Roccia F, Tavolaccini A, Dell'Acqua A, Fasolis M. An audit of mandibular fractures treated by intermaxillary fixation using intraoral cortical bone screws. J Craniomaxillofac Surg 2005;33:251.

8. Coletti DP, Salama A, Caccamese JF Jr. Application of intermaxillary fixation screws in maxillofacial trauma. J Oral Maxillofac Surg 2007;65: 1746.

9. Farr DR, Whear NM. Intermaxillary fixation screws and tooth damage. $\mathrm{Br}$ J Oral Maxillofac Surg 2002;40:84.

10. Ueki K, Marukawa K, Shimada M, Nakagawa K, Yamamoto E. The use of an intermaxillary fixation screw for mandibular setback surgery. J Oral Maxillofac Surg 2007;65:1562. the mandible. On the other hand, as the authors suggest, we usually insert the screws in the junction between the adhered and free gum to avoid pressure ulcers (Fig. 4). When we use MMF screws in orthognathic surgery (in subcondylar mandibular osteotomy) or panfacial fractures, on some occasions we insert 4 screws or more into each dental arcade (Fig. 5), two in the molar zone, applying force on the bone, and not the usual elastic fixation on orthodontic brackets, which can cause dental movement (Fig. 6). ${ }^{10}$

Rafael Martín-Granizo López

Servicio de Cirugía Oral y Maxilofacial Hospital Clínico San Carlos, Madrid, España 